Check for updates

The BMJ

Cite this as: BMJ 2021;374:n2086 http://dx.doi.org/10.1136/bmi.n2086 Published: 20 August 2021

\section{Covid-19: FDA set to grant full approval to Pfizer vaccine without public discussion of data}

\author{
Gareth lacobucci
}

Transparency advocates have criticised the US Food and Drug Administration's (FDA) decision not to hold a formal advisory committee meeting to discuss Pfizer's application for full approval of its covid-19 vaccine.

Last year the FDA said it was "committed to use an advisory committee composed of independent experts to ensure deliberations about authorisation or licensure are transparent for the public." ${ }^{1}$ But in a statement, the FDA told The BMJ that it did not believe a meeting was necessary ahead of the expected granting of full approval.

"The FDA has held numerous meetings of its Vaccines and Related Biological Products Advisory Committee (VRBPAC) related to covid-19 vaccines, including a 22 October $2020^{2}$ meeting to discuss, in general, the development, authorisation, and licensure of covid-19 vaccines," an FDA spokesperson said.

"The FDA also has held meetings of the VRBPAC on all three covid-19 vaccines authorised for emergency use and does not believe a meeting is needed related to this biologics license application."

The spokesperson added, "The Pfizer BioNTech covid-19 vaccine was discussed at the VRBPAC meeting on 10 December 2020. ${ }^{3}$ If the agency had any questions or concerns that required input from the advisory committee members we would have scheduled a meeting to discuss."

The vaccine has already been rolled out to millions of Americans through an emergency use authorisation. Companies typically apply for full approval after a longer period has elapsed so that more data are available for review.

But with the US government indicating this week that it plans to start making booster shots widely available next month, experts said the decision not to meet to discuss the data was politically driven.

\section{Data scrutiny}

Kim Witczak, a drug safety advocate who serves as a consumer representative on the FDA's

Psychopharmacologic Drugs Advisory Committee, ${ }^{4}$ said the decision removed an important mechanism for scrutinising the data.

"These public meetings are imperative in building trust and confidence especially when the vaccines came to market at lightning speed under emergency use authorisation," she said. "The public deserves a transparent process, especially as the call for boosters and mandates are rapidly increasing. These meetings offer a platform where questions can be raised, problems tackled, and data scrutinised in advance of an approval."
Witczak is one of the more than 30 signatories of a citizen petition ${ }^{5}$ calling on the FDA to refrain from fully approving any covid-19 vaccine this year to gather more data. She warned that without a meeting "we have no idea what the data looks like."

"It is already concerning that full approval is being based on 6 months' worth of data despite the clinical trials designed for two years," she said. "There is no control group after Pfizer offered the product to placebo participants before the trials were completed.

"Full approval of covid-19 vaccines must be done in an open public forum for all to see. It could set a precedent of lowered standards for future vaccine approvals."

\section{Public discussion}

Diana Zuckerman, president of the National Center for Health Research, who has also spoken at recent VRBPAC meetings, told The BMJ, "It's obvious that the FDA has no intention of hearing anyone else's opinion. But if you make decisions behind closed doors it can feed into hesitancy. It's important to have a public discussion about what kind of data are there and what the limitations are. As we think about risk versus benefit, we need to know."

Joshua Sharfstein, vice dean for public health practice and community engagement at the Johns Hopkins Bloomberg School of Public Health and former FDA deputy commissioner during the Obama administration, said that advisory committee meetings were more than just a way of receiving scientific input from outside experts. "It's also an opportunity to educate the public about the important work that the FDA has done reviewing an enormous amount of data about a product," he told The BMJ. "It's a chance for questions to be asked and answered, building public confidence.

"If there are no advisory committee meetings prior to licensure, the FDA should consider taking extra steps to explain the basis of its decisions to the public."

On 18 August, before the news that the FDA would not be holding a formal committee meeting, the president of the Infectious Diseases Society of America Barbara Alexander praised the impact of the VRBPAC meetings as "a critical and necessary part" of the process for assessing whether to give booster doses. ${ }^{6}$

Correction: We amended the reference list on 20 August 2021 to replace reference 5 .

Shah A, Marks P, Hahn S. Ensuring the safety and effectiveness of a covid-19 vaccine. www.healthaffairs.org/do/10.1377/hblog20200814.996612/full. 
2 FDA. Vaccines and related biological products advisory committee, October 22 2020, meeting announcement. 2020. www.fda.gov/advisory-committees/advisory-committee-calendar/vaccinesand-related-biological-products-advisory-committee-october-22-2020-meeting-announcement.

3 FDA. Vaccines and related biological products advisory committee, December 102020 , meeting announcement. 2020. www.fda.gov/advisory-committees/advisory-committee-calendar/vaccinesand-related-biological-products-advisory-committee-december-10-2020-meeting-announcement.

4 FDA. Psychopharmacologic drugs advisory committee roster. www.fda.gov/advisory-committees/psychopharmacologic-drugs-advisory-committee/psychopharmacologic-drugs-advisorycommittee-roster.

5 Wastila L, Doshi P, Merchant M, Witczak K. Why we petitioned the FDA to refrain from fully approving any covid-19 vaccine this year. BMJ Opinion. 8 June 2021.

https://blogs.bmi.com/bmi/2021/06/08/why-we-petitioned-the-fda-to-refrain-from-fully-approvingany-covid-19-vaccine-this-year.

6 IDSA. Response to plan for supplemental vaccine doses for vaccinated individuals. 18 August 2021. www.idsociety.org/news-publications-new/articles/2021/response-to-plan-for-supplementalvaccine-doses-for-vaccinated-individuals.

This article is made freely available for use in accordance with BMJ's website terms and conditions for the duration of the covid-19 pandemic or until otherwise determined by BMJ. You may use, download and print the article for any lawful, non-commercial purpose (including text and data mining) provided that all copyright notices and trade marks are retained. 